\title{
PERANCANGAN MODIFIKASI SISTEM INSTRUMENTASI DAN KENDALI PADA SISTEM IRADIASI RABBIT HIDROLIK REAKTOR RSG-GAS BERBASIS OPC SERVER DAN LABVIEW
}

\section{INSTRUMENTATION AND CONTROL SYSTEM MODIFICATION DESIGN OF HYDRAULIC IRRADIATION RABBIT SYSTEM AT THE G.A. SIWABESSY MULTI PURPOSE REACTOR (RSG-GAS) BASED ON OPC SERVER AND LABVIEW}

\author{
Ranji Gusman ${ }^{1}$, Sujarwono ${ }^{2}$, Heri Suherkiman ${ }^{3}$, Sunarko $^{4}$ \\ ${ }^{1,2,3.4}$ PRSG-BATAN Kawasan Puspiptek Gd. 30 Serpong, 15310 \\ Email: ranjigusman@batan.go.id
}

Diterima:,12 Oktober 2018 diperbaiki : 22 Oktober 2018, disetujui : 2 Nopember 2018

\begin{abstract}
ABSTRAK
PERANCANGAN MODIFIKASI SISTEM INSTRUMENTASI DAN KENDALI PADA SISTEM IRADIASI RABBIT HIDROLIK REAKTOR RSG-GAS BERBASIS OPC SERVER DAN LABVIEW. Sistem iradiasi rabbit hidrolik adalah salah satu fasilitas iradiasi yang terletak pada berilium reflektor teras reaktor yang digunakan untuk produksi radioisotop dan Analisa Aktivasi Neutron $(A A N)$. Saat ini sistem iradiasi rabbit hidrolik tersebut, pada sistem instrumentasi dan kendalinya telah menggunakan PLC Siemens S7-300 CPU tipe 315-2DP dengan komunikasi serial MPI sebagai pengendali dan HMI menggunakan perangkat lunak WinCC. Pada sistem tersebut, belum semua parameter operasi diproses PLC dan masih menggunakan perangkat keras untuk melakukan pengaturan waktu iradiasi. Pada tulisan ini, dilakukan perancangan modifikasi sistem instrumentasi dan kendali sistem iradiasi rabbit hidrolik. Metode perancangan dilakukan dengan mempelajari sistem iradiasi rabbit hidrolik, pengumpulan data $1 / O$ dan parameter operasi, mengganti dan menambahkan perangkat keras yang diperlukan, pengaturan koneksi PLC dan pembuatan HMI. Pada perancangan dilakukan pengolahan parameter operasi secara keseluruhan seperti data sensor temperature, konduktivitas, level air, dan tekanan serta optimasi PLC Siemens S7-300 dengan mengganti CPU lama dengan CPU baru tipe 315-2PN/DP yang dilengkapi fasilitas komunikasi LAN dan menggunakan antarmuka OPC server. Pada perancangan digunakan perangkat lunak LabVIEW sebagai HMI untuk tampilan pengaturan waktu dan start iradiasi, perekaman data iradiasi, status posisi kapsul iradiasi, status sensor dan visualisasi sistem proses rabbit hidrolik.
\end{abstract}

Kata kunci : perancangan modifikasi, sistem iradiasi rabbit hidrolik, OLE for Process Control $(O P C)$, LabVIEW.

\section{ABSTRACT}

INSTRUMENTATION AND CONTROL SYSTEM MODIFICATION DESIGN OF HYDRAULIC IRRADIATION RABBIT SYSTEM AT THE G.A. SIWABESSY MULTI PURPOSE REACTOR (RSG-GAS) BASED ON OPC SERVER AND LABVIEW. Hydraulic irradiation rabbit system is one of the irradiation facilities located on berrilium reflector used for radioisotope production and Neutron Activation Analysis (NAA). Instrumentation and control of hydraulic irradiation rabbit system used PLC Siemens S7-300 with 315-2DP CPU type as the controller with MPI serial 
communication and WinCC software as HMI. On the system, not all parameters processed by PLC and still used additional module to setting the irradiation timer. On this paper, instrumentation and control system modification design of hydraulic irradiation rabbit system have been done. Design methods are literature study of the system, I/O and operation parameters data collect, changing and adding the hardware, PLC connection setting and development of HMI. On the design, whole parameters processed and to optimized the PLC Siemens S7-300, the old CPU change to 315-2PN/DP CPU type with LAN facilities and used OPC server as an interface. On the design, LabVIEW software used as HMI which are consist of the view of irradiation start and timer setting, irradiation data record, the status of irradiation capsule,the status of sensors and process visualization of the system.

Keywords : modification design, hydraulic irradiation rabbit system, OLE for Process Control (OPC), LabVIEW.

\section{PENDAHULUAN}

Reaktor

Siwabessy

Serba Guna G.A. (RSG-GAS) adalah reaktor penelitian dengan fluks neutron termal sebesar $2 \times 10^{14} \mathrm{n} / \mathrm{cm}^{2} \mathrm{~s}$ yang mempunyai beberapa fasilitas iradiasi yang digunakan untuk melakukan penelitian, pengujian dan produksi radioisotop [1]. Fasilitas sistem iradiasi rabbit yang terdapat di reaktor RSG-GAS ada dua jenis yaitu sistem rabbit hidrolik dan sistem rabbit pneumatik. Sistem rabbit hidrolik menggunakan air sebagai media pengangkut kapsul iradiasi sedangkan sistem rabbit pneumatik menggunakan gas nitrogen sebagai media pengangkut kapsul iradiasi. Selain sebagai media pengangkut kapsul iradiasi, air dan gas nitrogen juga berfungsi sebagai pendingin kapsul selama proses iradiasi berlangsung. Reaktor RSG-GAS mempunyai empat buah sistem rabbit hidrolik dan satu buah sistem rabbit pneumatik yang dapat dioperasikan terpisah atau bersamaan. Sistem iradiasi rabbit adalah salah satu fasilitas iradiasi yang terletak di berilium reflektor yang digunakan untuk produksi radioisotop dan Analisa Aktivasi Neutron (AAN).

Sistem iradiasi rabbit reaktor RSG-GAS terdiri dari beberapa bagian yaitu stasiun pengiriman dan penerimaan kapsul iradiasi, tabung/pipa, dan sistem instrumentasi dan kendali yang terdiri dari sensor-sensor parameter operasi, modul pewaktu dan tombol start iradiasi dan PLC. Saat ini sistem instrumentasi dan kendali pada sistem iradiasi rabbit hidrolik reaktor RSG-GAS menggunakan PLC Siemens S7-300 dengan CPU tipe 315-2DP sebagai pengendali dengan Human Machine Interface (HMI) menggunakan perangkat lunak WinCC melalui komunikasi serial Message Passing Interface (MPI) dan juga masih menggunakan bantuan perangkat keras lain untuk melakukan pengaturan waktu iradiasi. Dengan kondisi tersebut, diperlukan suatu perancangan modifikasi dengan menggunakan PLC Siemens S7300 dengan CPU tipe 315-2PN/DP sebagai pengendali dan menggunakan perangkat lunak LabVIEW melalui OLE for Process Control (OPC) sebagai HMI. Oleh karena itu, perangkat keras pengaturan waktu iradiasi dapat dihilangkan, sehingga lebih efisien. Pada perancangan modifikasi sistem iradiasi rabbit hidrolik juga akan dibuat tampilan visualisasi dari proses operasi sistem sehingga dapat mempermudah operator dalam pengoperasian sistem iradiasi rabbit. Hasil dari penelitian ini diharapkan dapat membantu operator dan dapat meningkatkan mutu pelayanan utilisasi fasilitas iradiasi di reaktor RSG-GAS 
sehingga diperoleh sistem iradiasi rabbit hidrolik baru yang lebih optimal.

Tahun 2004 penelitian Hari Sudirdjo tentang refungsionalisasi sistem iradiasi rabbit reaktor RSG-GAS, dilakukan penggantian pengendali PLC dari PLC Siemens S5 ke PLC Siemens S7-300 [2]. Pada penelitian tersebut sistem iradiasi rabbit hidrolik belum dilakukan pemrosesan sensor-sensornya secara keseluruhan oleh PLC. Berdasarkan penelitian yang dilakukan baik di dalam dan luar negeri, sistem iradiasi rabbit dapat dibangun menggunakan PLC sebagai pengendali dan OPC sebagai komunikasi antar perangkat. Tahun 2010 penelitian S.S. Ismail melakukan pembuatan sistem transfer kapsul pneumatik dengan pengendali menggunakan PLC NaiSFPO [3]. Y.S Chung melakukan penelitian pembuatan sistem transfer kapsul pneumatik untuk analisa aktivasi neutron di reaktor Jordan [4]. Pada tahun 2007, Bunga Permata Adviani melakukan penelitian mengenai revitalisasi sistem transfer kapsul pneumatik di reaktor Kartini menggunakan OPC server dengan komunikasi menggunakan MPI dan LabVIEW sebagai HMI [5]. Perbedaan penelitian ini dengan penelitian sebelumnya adalah penelitian ini melakukan perancangan modifikasi dengan menggunakan PLC Siemens S7-
300 sebagai pengendali dengan $\mathrm{HMI}$ menggunakan perangkat lunak LabVIEW melalui OPC dengan antarmuka melalui jaringan LAN. Hal ini dikarenakan kemajuan teknologi dalam komunikasi data dan juga untuk mempersingkat waktu dalam melakukan pengaturan waktu iradiasi dengan menghilangkan modul pewaktu sehingga diharapkan menjadi lebih efisien dalam pengoperasiannya.

\section{Fasilitas Iradiasi Reaktor RSG-GAS}

Fasilitas-fasilitas iradiasi yang ada di reaktor RSG-GAS ditinjau dari segi letaknya dapat dibagi menjadi tiga, yaitu :

a. Fasilitas iradiasi yang terletak di dalam teras reaktor. Fasilitas iradiasi ini terdiri dari fasilitas iradiasi CIP (Central Irradiation Position) dan fasilitas iradiasi IP (Irradiation Position).

b. Fasilitas iradiasi yang terletak di luar teras reaktor. Fasilitas iradiasi ini terdiri dari enam buah tabung berkas neutron (neutron beam tube) dan Neutron Transmutation Doping (NTD).

c. Fasilitas iradiasi yang terletak di berilium reflektor. Fasilitas iradiasi ini terdiri dari sistem iradiasi rabbit dan Power Ramp Test Facility (PRTF). 


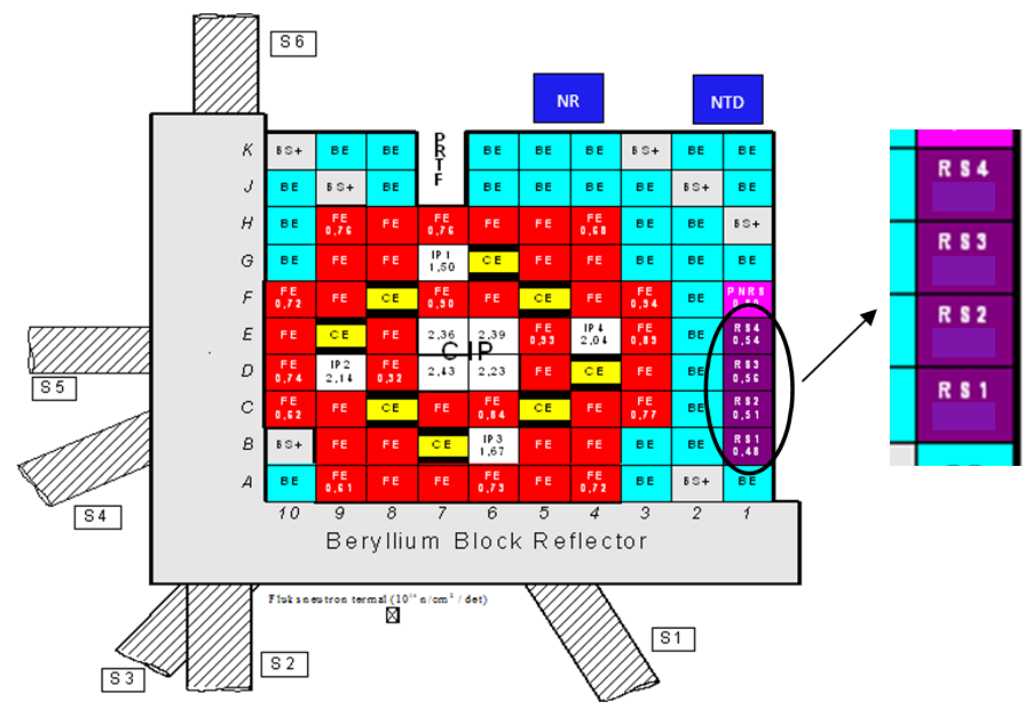

Gambar 1. Konfigurasi teras reaktor RSG-GAS.

Untuk lebih jelas mengenai fasilitas iradiasi dan posisinya pada teras reaktor RSG-GAS dapat dilihat pada Gambar 1. Teras reaktor RSG-GAS terdiri dari elemen bahan bakar (FE), elemen reflektor $(B E)$, elemen berilium reflektor dengan penyumbat $(B S+)$, elemen kendali (CE), dan berilium blok reflektor. Selain itu, teras reaktor RSGGAS juga dilengkapi dengan berbagai fasilitas iradiasi seperti Central Iradiation Position (CIP), Iradiation Position (IP), Neutron Radiography (NT), Neutron Transmutation Dopping (NTD), Power Ramp Test Facility (PRTF), tabung berkas neutron (S1 s.d. S6). Sistem iradiasi rabbit pneumatik (PNRS).
Sistem iradiasi rabbit hidrolik (RS1 s.d. RS4) ditandai dengan warna ungu yang terletak pada elemen reflektor (BE) di teras reaktor RSG-GAS.

\section{Sistem Iradiasi Rabbit Hidrolik RSG- GAS}

Reaktor RSG-GAS memiliki 4 buah sistem rabbit hidrolik yang dapat dioperasikan sendiri-sendiri atau bersama-sama sehingga dapat mengiradiasi beberapa cuplikan sekaligus dengan diameter dalam pipa pengirim sebesar $36 \mathrm{~mm}$ [6]. Sistem iradiasi rabbit hidrolik dapat digunakan untuk iradiasi sampel dengan waktu singkat (orde detik) sampai waktu yang relatif panjang (orde jam). Detail bagianbagian dari sistem iradiasi rabbit hidrolik RSG-GAS ditunjukkan pada Gambar 2. 


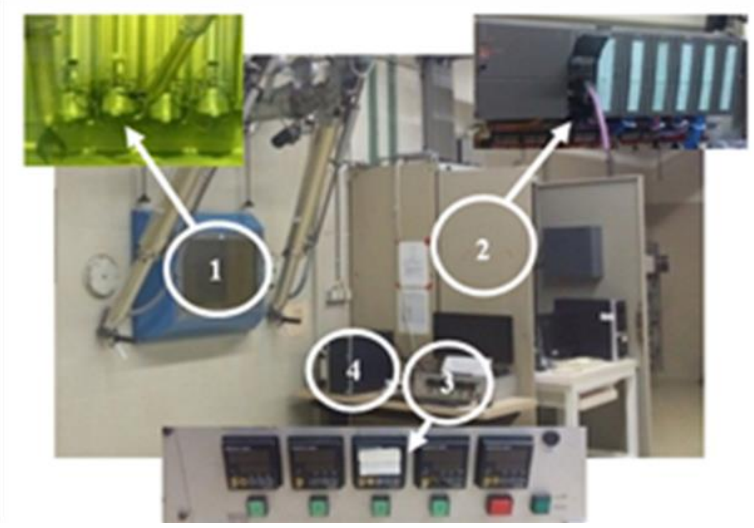

Gambar 2. Sistem iradiasi rabbit hidrolik.

Seperti diperlihatkan pada Gambar 2, bagian (1) merupakan stasiun penerimaan dan pengiriman kapsul dalam hotcell yang digunakan untuk memasukkan, mengeluarkan, dan tempat proses transfer kapsul selama proses iradiasi berlangsung. Bagian (2) adalah PLC Siemens S7-300 yang digunakan sebagai pengendali dari sistem iradiasi rabbit hidrolik dalam melakukan fungsinya. Bagian (3) merupakan pewaktu iradiasi dan tombol start iradiasi yang digunakan untuk menentukan lamanya proses iradiasi berlangsung dan memulai proses iradiasi. Sedangkan bagian (4) adalah personal komputer dengan perangkat lunak WinCC digunakan sebagai HMI.

Untuk lebih jelas mengenai cara kerja sistem iradiasi rabbit hidrolik reaktor RSG-GAS dapat dilihat pada blok diagram seperti pada Gambar 3. Pada Gambar 3, kapsul bahan target yang akan diiradiasi mula-mula berada pada stasiun penerimaan dan pengiriman di hotcell, pompa digunakan untuk mengirim kapsul ke teras reaktor dengan

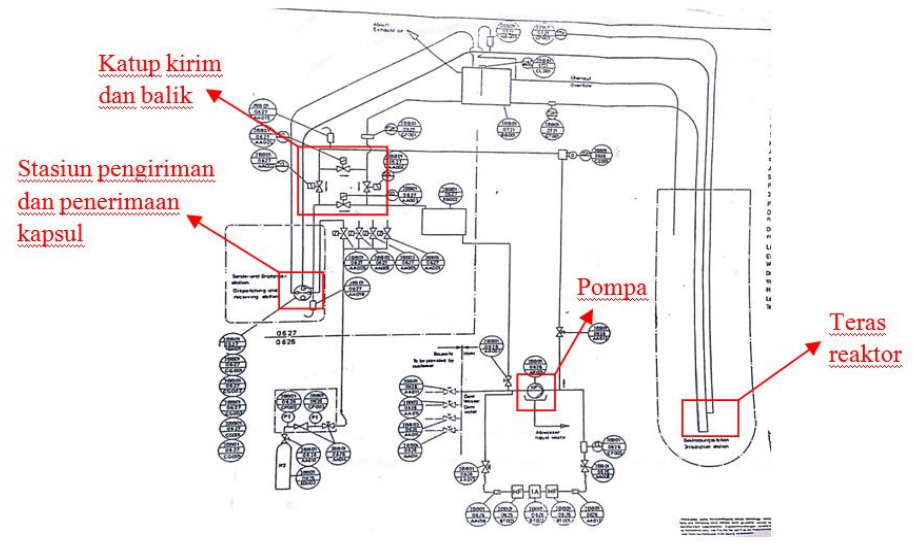

Gambar 3. Blok diagram sistem iradiasi rabbit 
air sebagai media pengangkut kapsul dengan mengatur kerja dari katup kirim atas perintah tombol start. Modul

\section{OLE for Process Control (OPC)}

OPC diluncurkan pertama kali pada tahun 1996, yang bertujuan menjadi sebuah perantara/antarmuka PLC dengan sistem Human Machine Interface (HMI) atau dengan sistem Supervisory Control and Data Acquisition (SCADA). OPC pertama yang diluncurkan adalah OPC Data Access (OPC-DA). OPC-DA memberikan spesifikasi standar dalam komunikasi data real-time dari perangkat akuisisi pewaktu akan memerintahkan kapsul untuk kembali ke stasiun penerimaan dan pengiriman apabila waktu iradiasi telah selesai.

data dengan perangkat HMI. OPC bekerja pada komputer client/server. Desain utama dari OPC adalah untuk mengakses data dari jaringan server, selain itu antarmuka OPC dapat digunakan pada berbagai aplikasi untuk mengambil dan menerima data dari perangkat pengendali seperti PLC, SCADA, dan perangkat kendali lainnya. Salah satu konfigurasi komunikasi menggunakan OPC ditampilkan pada Gambar 4.

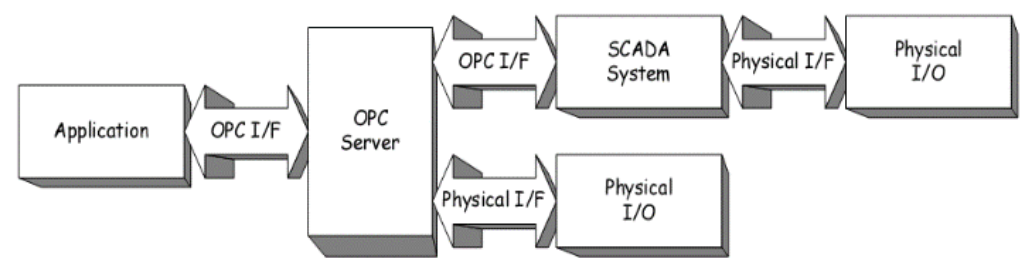

Gambar 4. Konfigurasi komunikasi OPC.

\section{LabVIEW}

LabVIEW (Laboratory Virtual Instrumentation Engineering Workbench) adalah platform untuk bahasa pemrograman visual dari National Instruments yang membantu para insinyur merancang sampai kepengujian dari skala kecil hingga skala besar [7]. LabVIEW umumnya digunakan untuk akuisisi data, kontrol instrumen, dan otomasi industri dengan menggunakan bahasa pemrograman berbasis grafis. Program LabVIEW dikenal dengan sebutan Virtual Instruments (VI) karena tampilan dan operasinya menyerupai sebuah instrumen. Bahasa pemrograman grafis yang digunakan memungkinkan seorang programmer pemula dapat dengan mudah membangun sebuah program sederhana.

\section{Programmable Logic Controller (PLC) Siemens S7-300}

PLC adalah suatu pengendali khusus berbasis mikroprosesor yang menggunakan memori untuk menyimpan instruksi dan untuk menerapkan fungsifungsi seperti logika, sequencing, pewaktu (timing), pencacah (counting) dan aritmetika untuk mengontrol mesinmesin dan proses-proses [8]. Salah satu perusahaan yang bergerak di bidang teknologi otomasi dengan memproduksi perangkat PLC adalah Siemens. Salah satu jenis modul CPU PLC Siemens S7300 yang sering digunakan dalam melakukan fungsi kendali adalah CPU tipe 315-2 PN/DP. CPU ini dilengkapi 
fasilitas antarmuka PROFINET yang dapat digunakan untuk melakukan komunikasi antara sistem PLC dengan pengguna menggunakan OPC melalui Local Area Network (LAN). Adapun detail
CPU PLC Siemens S7-300 tipe 315-2 PN/DP dapat dilihat pada Gambar 5.

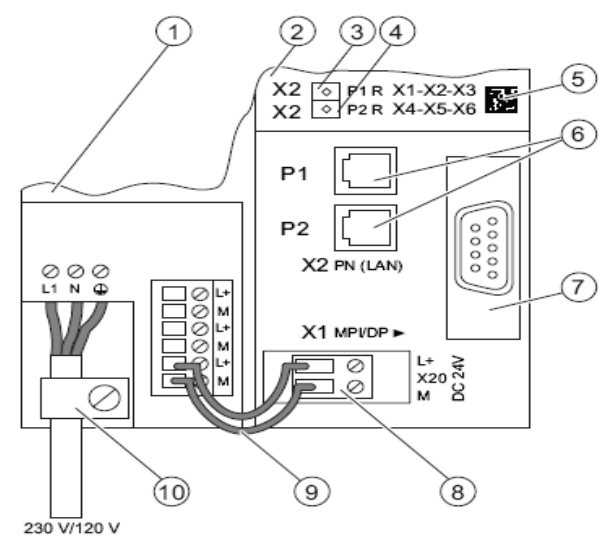

Gambar 5. CPU PLC Siemens S7-300 tipe 315-2 PN/DP.

\section{METODOLOGI PENELITIAN}

\section{Perancangan Sistem}

Pada tahun 2004, sistem iradiasi rabbit hidrolik telah mengalami refungsionalisasi yang sebelumnya menggunakan perangkat kendali PLC Siemens S5 menjadi PLC Siemens S7300. Saat itu sistem iradiasi rabbit hidrolik reaktor RSG-GAS terdiri blok input yang terdiri dari tombol start iradiasi, sensor posisi kapsul, dan pewaktu iradiasi. Sedangkan untuk sensor level air, sensor tekanan, sensor laju alir, sensor temperatur, dan sensor konduktivitas belum dimasukkan ke sistem. Data masukan tersebut akan diolah oleh PLC sebagai pengendali dan kemudian menginisiasi aktuator yang berada pada blok output seperti katup dan pompa. Untuk lebih jelas mengenai masalah yang ada pada instrumentasi dan kendali sistem iradiasi rabbit hidrolik reaktor RSG-GAS dapat dilihat blok diagram dari sistem sebelum modifikasi seperti pada Gambar 6.

Sensor posisi kapsul pada sistem iradiasi rabbit hidrolik terdiri dari 4 posisi yaitu posisi charge/discharge, posisi flooding, posisi sending/receive, dan posisi drying. Untuk mengubah posisi tersebut dapat dilakukan dengan memutar tuas drum stasiun pengiriman dan penerimaan kapsul sistem iradiasi rabbit hidrolik yang terletak didalam hotcell dengan bantuan manipulator. Tombol start iradiasi digunakan untuk mengirim kapsul ke teras reaktor setelah dilakukan pengaturan pewaktu iradiasi. Pewaktu iradiasi sistem rabbit hidrolik masih menggunakan modul timer yang apabila waktu tercapai maka akan 
menghentikan proses iradiasi dan akan memerintakan pompa untuk mengirim kembali kapsul ke stasiun pengiriman dan penerimaan melalui modul Digital Output (DO). Untuk komunikasi antara PLC dan personal komputer, digunakan
$\mathrm{HMI}$ dengan perangkat lunak WinCC melalui komunikasi serial MPI dan personal komputer tersebut menampilkan posisi kapsul sistem iradiasi rabbit.

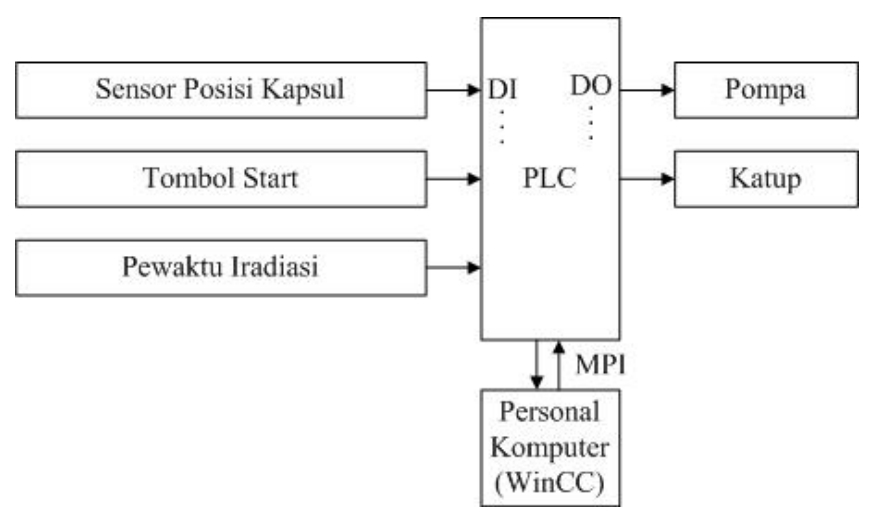

Gambar 6. Blok diagram sebelum modifikasi.

\begin{abstract}
Dengan kondisi sistem iradiasi rabbit hidrolik reaktor RSG-GAS tersebut, maka dapat dilakukan perancangan modifikasi dari sistem instrumentasi dan kendali yaitu dengan menghilangkan masukan tombol start dan pewaktu iradiasi serta dilakukan pembuatan HMI dengan menggunakan perangkat lunak LabVIEW melalui komunikasi OPC menggunakan jaringan LAN sehingga nantinya pada personal komputer akan terdapat pewaktu iradiasi dan tombol start iradiasi sebagai
\end{abstract}

masukan ke PLC, posisi kapsul, status sensor, data sampel iradiasi, dan visualisasi dari proses sistem iradisi rabbit hidrolik. Adapun blok diagram sistem sistem iradiasi rabbit setelah modifikas untuk kanal 1 (RS1) ditunjukkan pada Gambar 7. Untuk sistem iradiasi rabbit hidrolik yang lain (RS2 s.d. RS4) memiliki blok diagram yang sama dengan RS1 hanya berbeda pada alamat I/O (Input/Output) PLC yang digunakan. 


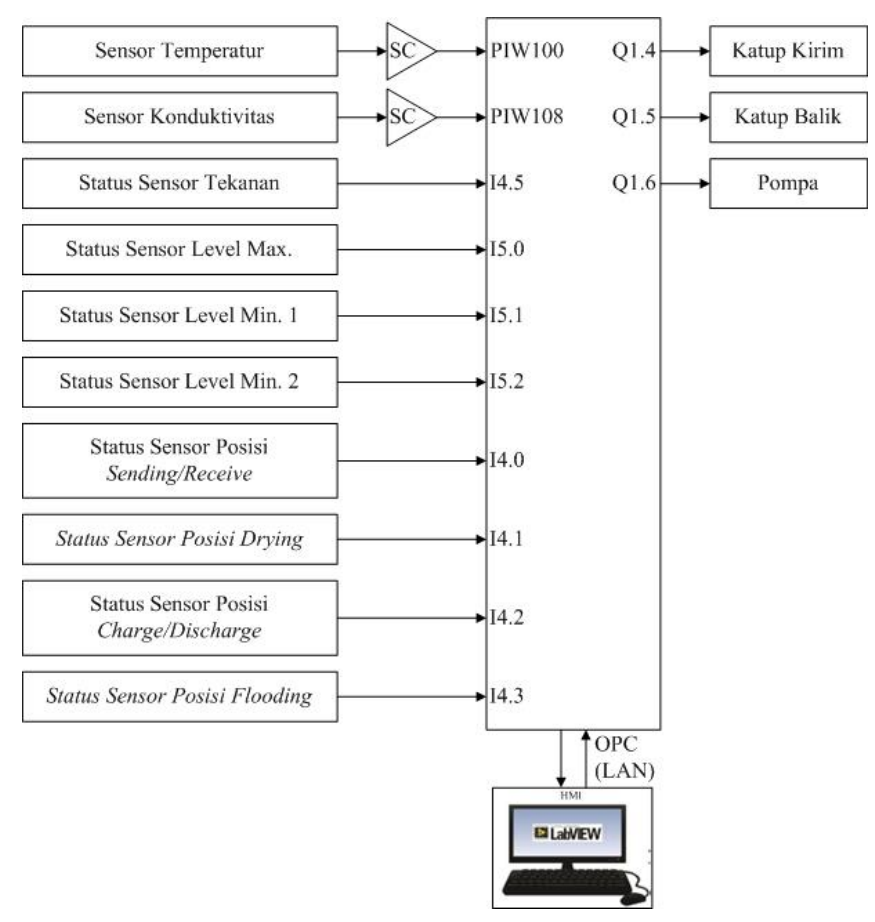

Gambar 7. Rancangan blok diagram modifikasi sistem iradiasi rabbit hidrolik.

Berbeda seperti blok diagram kondisi sistem iradiasi rabbit hidrolik saat refungsionalisasi pada tahun 2004, rancangan blok diagram sistem iradiasi rabbit hidrolik setelah modifikasi pada Gambar 7 dapat dilihat bahwa perangkat keras tombol start iradiasi dan pewaktu iradiasi telah dihilangkan dan akan digantikan pada $\mathrm{HMI}$ di PC dengan perangkat lunak LabVIEW dan status sensor-sensor telah masuk ke modul analog dan digital input PLC. Selain itu komunikasi data yang digunakan menggunakan OPC server melalui jaringan LAN.

Dari hasil rancangan blok diagram setelah modifikasi, maka dapat dilakukan perancangan diagram alir modifikasi sistem iradiasi rabbit hidrolik reaktor RSG-GAS ditunjukkan pada Gambar 8. 


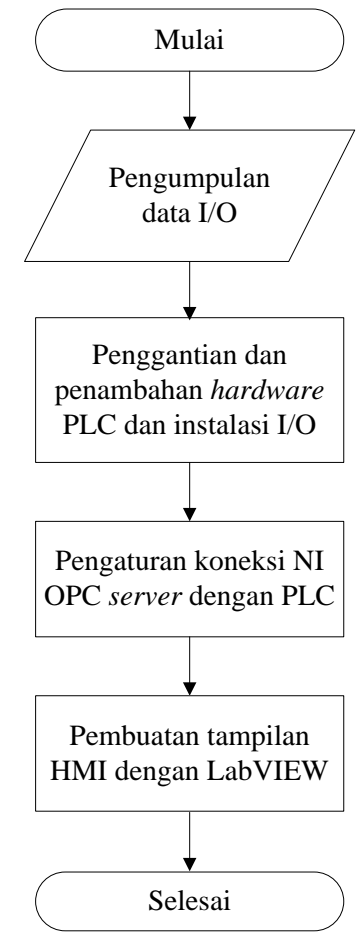

Gambar 8. Diagram alir perancangan modifikasi sistem iradiasi rabbit hidrolik reaktor RSG-GAS.

Berdasarkan diagram alir perancangan, adapun tahapan proses perancangan dari penelitian ini adalah sebagai berikut :

a. Melakukan pengumpulan data I/O dari PLC sistem iradiasi rabbit hidrolik berupa data alamat atau data memori (flag).

b. Melakukan penggantian hardware PLC berupa CPU PLC Siemens S7300 tipe 315-2PN/DP dan penambahan modul Analog Input (AI) tipe SM331 Al 8x16 bit.

c. Melakukan pengaturan koneksi NI OPC server dengan PLC Siemens S7-300 melalui protokol TCP/IP.

d. Melakukan tagging data PLC yang akan ditampilkan pada tampilan $\mathrm{HMI}$ LabVIEW pada NI OPC server.

\section{HASIL DAN PEMBAHASAN}

Dari hasil pengumpulan data I/O pada perancangan modifikasi sistem iradiasi rabbit, dilakukan identifikasi parameter yang akan dimodifikasi. Pada proses identifikasi, dilakukan pengecekan sensor-sensor parameter operasi dari sistem iradisi rabbit seperti sensor level air, tekanan, temperatur, konduktivitas dan laju alir.

Pengecekan sensor level air dilakukan dengan simulasi menaikkan dan menurunkan sensor hingga menyentuh 3 posisi level switch (maksimum, minimum 1 dan minimum 2). Dari hasil pengecekan, sensor level air masih dalam kondisi baik. Pengecekan sensor tekanan dilakukan dengan mengoperasikan sistem. Sensor tekanan ini mengindikasikan kapsul telah ada di teras reaktor. Dari hasil pengecekan, sensor tekanan masih belum bekerja dengan baik karena saat dilakukan pengiriman kapsul sensor memberikan perubahan logika akibat kerja dari katup sehingga tidak mengindikasikan posisi kapsul yang sebenarmya. Pengecekan sensor temperatur dilakukan dengan mengkalibrasi sensor dan kanal pengukuran temperatur dengan sumber temperatur standar. Dari hasil pengecekan, sensor temperatur masih dalam kondisi baik. Pengecekan sensor konduktivitas dilakukan dengan mengkalibrasi kanal pengukuran konduktivitas dengan sumber arus 4-20 $\mathrm{mA}$. Sensor konduktivitas tidak dilakukan kalibrasi karena ketidaktersediaan sumber standar konduktivitas yang sesuai dengan range kerja sensor. Dari hasil pengecekan, kanal pengukuran sensor konduktivitas masih dalam kondisi baik. Pengecekan sensor laju alir dilakukan dengan mengoperasikan sistem dan mengamati sinyal keluaran sensor dengan osiloskop. Dari hasil 
pengecekan, sensor laju alir telah mengalami kerusakan karena sensor tidak memberikan sinyal keluaran yang sebenarnya sehingga dalam modifikasi nantinya belum dilakukan pengolahan data laju alir.

Berdasarkan hasil identifikasi sistem dan pengecekan sensor diperoleh data identifikasi seperti pada tabel 1 .

Tabel 1. Hasil identifikasi parameter.

\begin{tabular}{|c|c|c|c|c|c|}
\hline No. & Perangkat & Status & Output & \multicolumn{2}{|c|}{ Alamat } \\
\hline \multirow{4}{*}{1} & \multirow{4}{*}{$\begin{array}{l}\text { Sensor } \\
\text { level air } \\
\text { (level } \\
\text { switch) }\end{array}$} & \multirow{4}{*}{$\begin{array}{l}\text { Digital } \\
\text { status } \\
\text { level } \\
\max \end{array}$} & \multirow{4}{*}{$\begin{array}{l}\text { Teganga } \\
\mathrm{n} \\
(24 \mathrm{~V})\end{array}$} & RS1 & I 5.0 \\
\hline & & & & RS2 & I 7.0 \\
\hline & & & & RS3 & I 9.0 \\
\hline & & & & RS4 & I 11.0 \\
\hline \multirow{4}{*}{2} & \multirow{4}{*}{$\begin{array}{l}\text { Sensor } \\
\text { level air } \\
\text { (level } \\
\text { switch) } \\
\end{array}$} & \multirow{4}{*}{$\begin{array}{l}\text { Digital } \\
\text { status } \\
\text { level } \\
\min 1 \\
\end{array}$} & \multirow{4}{*}{$\begin{array}{l}\text { Teganga } \\
\text { n } \\
(24 \mathrm{~V})\end{array}$} & RS1 & I 5.1 \\
\hline & & & & RS2 & I 7.1 \\
\hline & & & & RS3 & I 9.1 \\
\hline & & & & RS4 & I 11.1 \\
\hline \multirow{4}{*}{3} & \multirow{4}{*}{$\begin{array}{l}\text { Sensor } \\
\text { level air } \\
\text { (level } \\
\text { switch) }\end{array}$} & \multirow{4}{*}{$\begin{array}{l}\text { Digital } \\
\text { status } \\
\text { level } \\
\text { min } 2 \\
\end{array}$} & \multirow{4}{*}{$\begin{array}{l}\text { Teganga } \\
\mathrm{n} \\
(24 \mathrm{~V})\end{array}$} & RS1 & I 5.2 \\
\hline & & & & RS2 & I 7.2 \\
\hline & & & & RS3 & I 9.2 \\
\hline & & & & RS4 & I 11.2 \\
\hline \multirow{4}{*}{4} & \multirow{4}{*}{$\begin{array}{l}\text { Sensor } \\
\text { tekanan } \\
\text { (pressure } \\
\text { switch) }\end{array}$} & \multirow{4}{*}{$\begin{array}{l}\text { Digital } \\
\text { status } \\
\text { tekanan } \\
\text { high } \\
\end{array}$} & \multirow{4}{*}{$\begin{array}{l}\text { Teganga } \\
\mathrm{n} \\
(24 \mathrm{~V})\end{array}$} & RS1 & I 4.5 \\
\hline & & & & RS2 & I 6.5 \\
\hline & & & & RS3 & I 8.5 \\
\hline & & & & RS4 & I 10.5 \\
\hline \multirow{4}{*}{5} & \multirow{4}{*}{$\begin{array}{l}\text { Sensor } \\
\text { temperatur } \\
\text { (termocou } \\
\text { ple) }\end{array}$} & \multirow{4}{*}{$\begin{array}{l}\text { Analog } \\
\text { status } \\
\text { temperat } \\
\text { ur }\end{array}$} & \multirow{4}{*}{$\begin{array}{l}\text { Arus } \\
(4-20 \\
\mathrm{mA})\end{array}$} & RS1 & $\begin{array}{c}\text { PIW1 } \\
00\end{array}$ \\
\hline & & & & RS2 & $\begin{array}{c}\text { PIW1 } \\
02\end{array}$ \\
\hline & & & & RS3 & $\begin{array}{c}\text { PIW1 } \\
04 \\
\end{array}$ \\
\hline & & & & RS4 & $\begin{array}{c}\text { PIW1 } \\
06\end{array}$ \\
\hline \multirow{4}{*}{6} & \multirow{4}{*}{$\begin{array}{l}\text { Sensor } \\
\text { konduktivi } \\
\text { tas }\end{array}$} & \multirow{4}{*}{$\begin{array}{l}\text { Analog } \\
\text { status } \\
\text { kondukt } \\
\text { ivitas }\end{array}$} & \multirow{4}{*}{$\begin{array}{l}\text { Arus } \\
(4-20 \\
\mathrm{mA})\end{array}$} & RS1 & $\begin{array}{c}\text { PIW1 } \\
08 \\
\end{array}$ \\
\hline & & & & RS2 & $\begin{array}{c}\text { PIW1 } \\
10 \\
\end{array}$ \\
\hline & & & & RS3 & $\begin{array}{c}\text { PIW1 } \\
12 \\
\end{array}$ \\
\hline & & & & RS4 & $\begin{array}{c}\text { PIW1 } \\
14 \\
\end{array}$ \\
\hline \multirow{4}{*}{7} & \multirow{4}{*}{$\begin{array}{l}\text { Sensor } \\
\text { posisi } \\
\text { charge/dis } \\
\text { charge }\end{array}$} & Digital & & RS1 & I 4.2 \\
\hline & & status & $\begin{array}{l}\text { reganga } \\
n\end{array}$ & RS2 & I 6.2 \\
\hline & & sensor & $(24 \mathrm{~V})$ & RS3 & I 8.2 \\
\hline & & $\mathrm{ON}$ & & RS4 & I 10.2 \\
\hline & Sensor & Digital & & RS1 & I 4.3 \\
\hline 8 & posisi & status & $\mathrm{n}$ & RS2 & I 6.3 \\
\hline & flooding & sensor & $(24 \mathrm{~V})$ & RS3 & I 8.3 \\
\hline & & $\mathrm{ON}$ & & RS4 & I 10.3 \\
\hline & Sensor & Digital & & RS1 & I 4.0 \\
\hline 9 & posisi & status & Ieganga & RS2 & I 6.0 \\
\hline 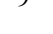 & sending/re & sensor & $(24 \mathrm{~V})$ & RS3 & I 8.0 \\
\hline & ceive & $\mathrm{ON}$ & & RS4 & I 10.0 \\
\hline 10 & Sensor & Digital & Teganga & RS1 & I 4.1 \\
\hline & posisi & status & $\mathrm{n}$ & RS2 & I 6.1 \\
\hline
\end{tabular}

\begin{tabular}{|c|c|c|c|c|c|}
\hline \multirow[t]{3}{*}{ No. } & \multirow{3}{*}{$\begin{array}{l}\text { Perangkat } \\
\text { drying }\end{array}$} & \multirow{3}{*}{$\begin{array}{l}\text { Status } \\
\text { sensor } \\
\text { ON }\end{array}$} & \multirow{3}{*}{$\frac{\text { Output }}{(24 \mathrm{~V})}$} & \multicolumn{2}{|c|}{ Alamat } \\
\hline & & & & RS3 & I 8.1 \\
\hline & & & & RS4 & I 10.1 \\
\hline \multirow{4}{*}{11} & \multirow{4}{*}{$\begin{array}{l}\text { Tombol } \\
\text { start }\end{array}$} & \multirow{4}{*}{$\begin{array}{l}\text { Digital } \\
\text { status } \\
\text { tombol } \\
\text { ON }\end{array}$} & \multirow{4}{*}{ - } & RS1 & $\begin{array}{c}\mathrm{M} \\
100.1\end{array}$ \\
\hline & & & & RS2 & $\begin{array}{c}\mathrm{M} \\
100.2 \\
\end{array}$ \\
\hline & & & & RS3 & $\begin{array}{c}\mathrm{M} \\
100.3 \\
\end{array}$ \\
\hline & & & & RS4 & $\begin{array}{c}\mathrm{M} \\
100.4 \\
\end{array}$ \\
\hline \multirow{4}{*}{12} & \multirow{4}{*}{$\begin{array}{l}\text { Waktu } \\
\text { iradiasi } \\
\text { selesai }\end{array}$} & \multirow{4}{*}{$\begin{array}{l}\text { Digital } \\
\text { status } \\
\text { iradiasi } \\
\text { selesai }\end{array}$} & \multirow{4}{*}{ - } & RS1 & $\begin{array}{c}\mathrm{M} \\
200.1 \\
\end{array}$ \\
\hline & & & & RS2 & $\begin{array}{c}\mathrm{M} \\
200.2\end{array}$ \\
\hline & & & & RS3 & $\begin{array}{c}\mathrm{M} \\
200.3 \\
\end{array}$ \\
\hline & & & & RS4 & $\begin{array}{c}\mathrm{M} \\
200.4 \\
\end{array}$ \\
\hline \multirow{4}{*}{13} & \multirow{4}{*}{$\begin{array}{l}\text { Katup } \\
\text { kirim }\end{array}$} & \multirow{4}{*}{$\begin{array}{l}\text { Digital } \\
\text { status } \\
\text { output }\end{array}$} & \multirow{4}{*}{$\begin{array}{l}\text { Teganga } \\
\mathrm{n} \\
(24 \mathrm{~V})\end{array}$} & RS1 & Q 4.1 \\
\hline & & & & RS2 & Q 5.1 \\
\hline & & & & RS3 & Q 6.1 \\
\hline & & & & RS4 & Q 7.1 \\
\hline \multirow{4}{*}{14} & \multirow{4}{*}{$\begin{array}{l}\text { Katup } \\
\text { balik }\end{array}$} & \multirow{4}{*}{$\begin{array}{l}\text { Digital } \\
\text { status } \\
\text { output }\end{array}$} & \multirow{4}{*}{$\begin{array}{l}\text { Teganga } \\
\mathrm{n} \\
(24 \mathrm{~V})\end{array}$} & RS1 & Q 4.0 \\
\hline & & & & RS2 & Q 5.0 \\
\hline & & & & RS3 & Q 6.0 \\
\hline & & & & RS4 & Q 7.0 \\
\hline \multirow{4}{*}{15} & \multirow{4}{*}{ Pompa } & \multirow{4}{*}{$\begin{array}{l}\text { Digital } \\
\text { status } \\
\text { output }\end{array}$} & \multirow{4}{*}{$\begin{array}{l}\text { Teganga } \\
\mathrm{n} \\
(24 \mathrm{~V})\end{array}$} & RS1 & $\mathrm{Q} 0.0$ \\
\hline & & & & RS2 & Q 1.0 \\
\hline & & & & RS3 & Q 2.0 \\
\hline & & & & RS4 & Q 3.0 \\
\hline
\end{tabular}

Gambar rancangan modifikasi dari HMI sistem iradiasi rabbit hidrolik RSG-GAS ditunjukkan seperti pada Gambar 9

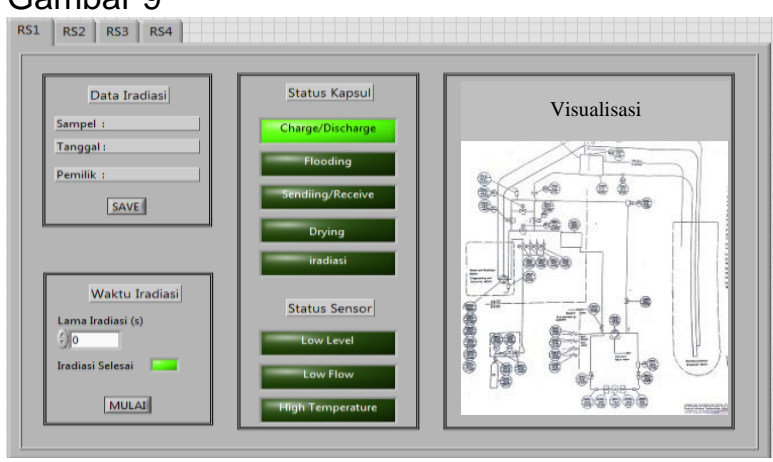

Gambar 9. Rancangan HMI. 

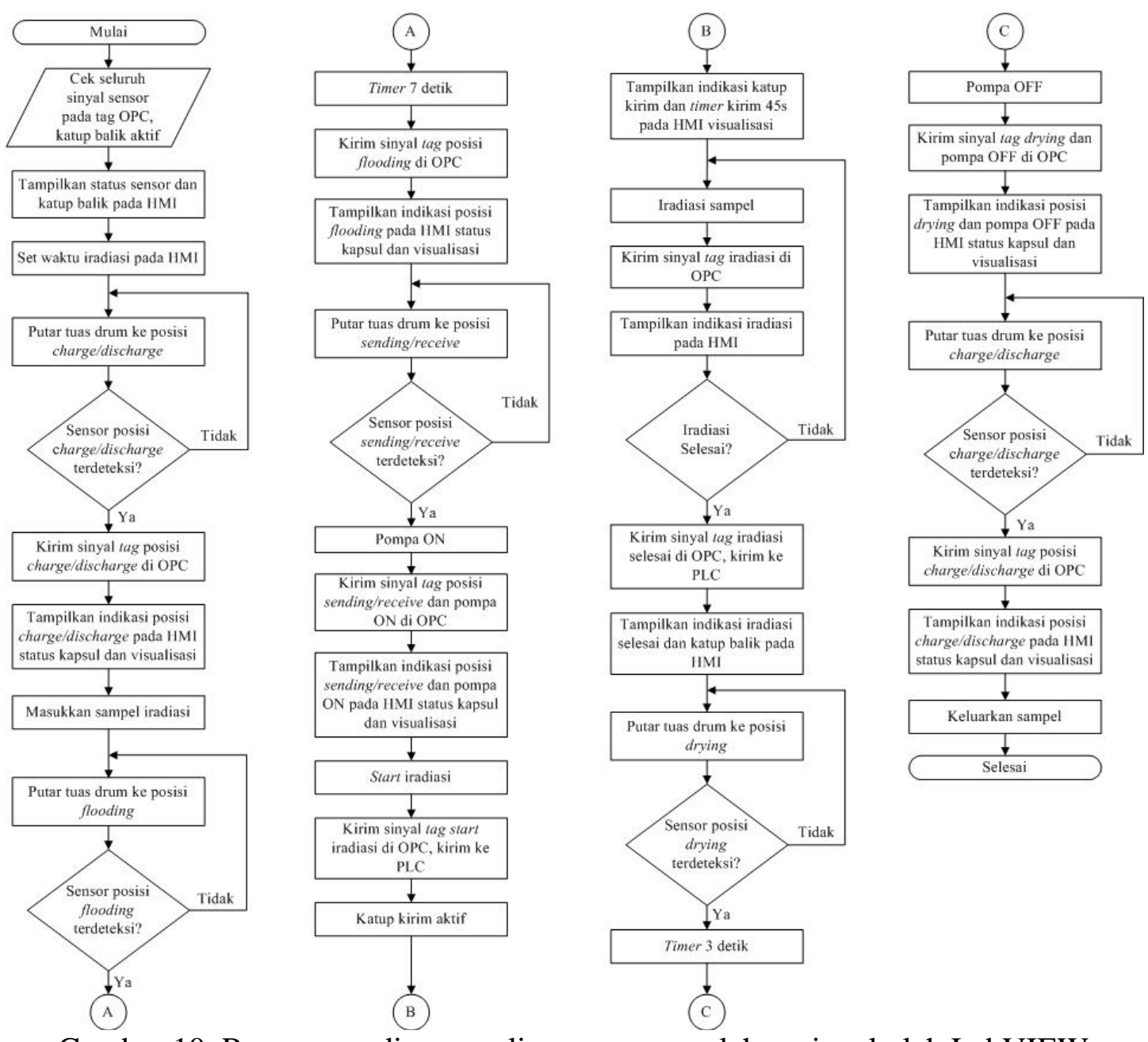

Gambar 10. Rancangan diagram alir proses pengolahan sinyal oleh LabVIEW

Dapat dilihat rancangan $\mathrm{HMI}$ ini nantinya terdiri dari tab untuk masing-masing kanal sistem iradiasi rabbit hidrolik. Tiap tab terdapat sistem perekaman data iradiasi yang akan tersimpan pada drive komputer, sistem pewaktu dan start iradiasi untuk menggantikan modul pewaktu sebelumnya, status kapsul, status sensor dan visualisasi proses iradiasi. Dari hasil perancangan tersebut, untuk mempermudah dalam mengaplikasikan kegiatan modifikasi sistem iradiasi rabbit hidrolik, maka diperlukan suatu diagram alir proses pengolahan sinyal oleh LabVIEW sebagai HMI seperti ditunjukkan pada Gambar 10. Pada perancangan juga dilakukan simulasi program dan komunikasi antara PLC dan HMI menggunakan LabVIEW. Simulasi terdiri dari simulasi sinyal digital input, sinyal digital output, sinyal analog input dan simulasi pewaktu dan start iradiasi menggunakan alamat memori (flag) pada PLC. Adapun hasil simulasi adalah seperti pada Tabel 2. 
Tabel 2. Simulasi program.

\begin{tabular}{|c|c|c|c|}
\hline No. & Simulasi & OPC & HMI \\
\hline \multirow{2}{*}{1} & \multirow{2}{*}{ Digital input } & 0 & Indikator off \\
\hline & & 1 & Indikator on \\
\hline \multirow{2}{*}{2} & \multirow{2}{*}{ Digital output } & 0 & Indikator off \\
\hline & & 1 & Indikator on \\
\hline 3 & $\begin{array}{l}\text { Analog input } \\
\text { sensor } \\
\text { temperatur } \\
(4-20 \mathrm{~mA})\end{array}$ & $\begin{array}{c}0- \\
27651\end{array}$ & $0-250^{\circ} \mathrm{C}$ \\
\hline 4 & $\begin{array}{l}\text { Analog input } \\
\text { sensor } \\
\text { konduktivitas } \\
(4-20 \mathrm{~mA})\end{array}$ & $\begin{array}{c}0- \\
27651\end{array}$ & $\begin{array}{l}0-20 \\
\mathrm{uS} / \mathrm{cm}\end{array}$ \\
\hline \multirow{2}{*}{5} & \multirow{2}{*}{$\begin{array}{l}\text { Pewaktu } \\
\text { iradiasi }\end{array}$} & 0 & Indikator off \\
\hline & & 1 & Indikator on \\
\hline \multirow[b]{2}{*}{6} & \multirow{2}{*}{ Start iradiasi } & 0 & Indikator off \\
\hline & & 1 & Indikator on \\
\hline
\end{tabular}

Berdasarkan hasil perancangan yang telah didapat, maka proses perancangan ini nantinya dipakai sebagai acuan modifikasi sistem iradiasi rabbit hidrolik RSG-GAS menggunakan OPC server dan LabVIEW sebagai HMI.

\section{KESIMPULAN}

Perancangan modifikasi sistem iradiasi rabbit hidrolik reaktor RSG-GAS berbasis OPC server dan LabVIEW telah berhasil dilakukan. Hasil identifikasi sensor menunjukkan bahwa sebagian besar sensor masih berfungsi dengan baik. Adapun sensor yang tidak berfungsi adalah sensor laju alir sehingga diperlukan revitalisasi. Pada perancangan $\mathrm{HMI}$ setelah modifikasi nantinya akan ditambahkan tampilan pengaturan waktu iradiasi dan start iradiasi untuk menggantikan modul pewaktu dan tombol start iradiasi. Selain itu juga ditambahkan tampilan rekaman data iradiasi yang akan tersimpan pada drive komputer, tampilan status kapsul dan sensor, serta tampilan visualisasi dari kerja sistem sehingga diharapkan dapat membantu operator dalam melakukan pemantauan proses iradiasi di sistem iradiasi rabbit hidrolik.

\section{DAFTAR PUSTAKA}

[1] Sutrisno, Suwoto and Royadi, "Evaluasi Pemanfaatan Fasilitas Iradiasi RSG-GAS Pada Tahun 2006," Yogyakarta, 2007.

[2] H. Sudirdjo, Sujarwono, Sutrisno and Royadi, "Refungsionalisasi Sistem Rabbit," Serpong, 2004.

[3] S. S. Ismail, "A New Automated Sample Transfer System for Instsrumental Neutron Activation Analysis," Journal of Automated Methods and Management in Chemistry, vol. 2010, 2010.

[4] Y. S. Chung, S. H. Kim, J. H. Moon, J. B. Choi, J. M. Lee and J. S. Ryu, "Design and Development of Fast Pneumatic Transfersystem (PTS) for Instrumental Neutron Activationanalysis at Jordan Research Reactor," Daejeon.

[5] B. P. Adviani, Revitalisasi Sistem Transfer Kapsul Pneumatik di Reaktor Kartini, Yogyakarta: STTNBATAN, 2017.

[6] E. Ratnawati, S. Hartaman and K. Mustofa, "Uji Fungsi Fasilitas Iradiasi Sistem Rabbit Pneumatik Reaktor RSG-GAS Menggunakan Bahan Acuan Standar," Yogyakarta, 2012.

[7] A. N. Rachman, "Pengembangan Sistem Online Monitoring Parameter Proses RSG-GAS Berbasis OPC," Yogyakarta, 2015.

[8] W. Bolton, Programmable Logic Controller, 4th ed., Burlington: Elsevier Newnes, 2006. 
Buletin Pengelolaan Reaktor Nuklir

Bulletin of Nuclear Reactor Management

Vol. XV, No.2,Oktober 2018:hal. 1-13 